\title{
INVESTIGATION OF CLASSROOM APPLICATIONS FOR \\ MULTICULTURAL EDUCATION IN TERMS OF VARIOUS \\ VARIABLES
}

\author{
Prof. Ass. Soner YILDIRIM*, \\ Prof. Ass. Münevver MUYO YILDIRIM** \\ *Prizren University “UKSHIN HOTI, Faculty of Education, soner.yildirim@uni-prizren.com \\ **Prizren University “UKSHIN HOTI, Faculty of Education, munevvermuyo@ gmail.com
}

\begin{abstract}
Article history:
Accepted 17 April 2019

Available online 30 April 2019

Keywords:

Multicultural Education,

Classroom Practices for Multicultural

Education,

Teaching Cultural Differences

A b s t r a c t

In this study, it was examined whether the teachers' in-class practices towards multicultural education in Kosovo differ according to gender, professional seniority, mother tongue, level and branch variables. Descriptive screening model was used in the study. The study group consisted of 975 Turkish, Albanian and Bosnian teachers working in the provinces of Prizren, Pristina, Mamusha, Reçane and Restelitsa in the 2016-2017 academic year. The education In-Class Practices Scale developed by the researcher as a data collection tool to determine the classroom practices of teachers for multicultural educational practices was applied in this study. The results of the study showed that some variables differed significantly on classroom teaching practices. These are the mother tongue, the level and the branch variables. On the other hand, it was determined that gender and professional seniority variables did not cause a significant difference in classroom practices. As a result of the study, it has been suggested that in-service training for teaching cultural differences for Turkish, Albanian and Bosnian native language teachers, the number of activities aimed at teaching cultural differences in activities related to different cultural values in schools' textbooks should be increased and new program designs for multicultural education should be developed.
\end{abstract}

\section{Introduction}

Living together with different cultures in different societies, knowledge, skills and experiences gained throughout life enrich the perspective of man. At the same time, it opens the door to a quality life opportunity both socially and economically. Individuals who have a habit of living in a society with different cultures have the opportunity to be more open-minded, tolerant and alive. Respect for differences, people living in harmony with various cultures, people gain experience in the differences, they can make their lives easier and colorful life experiences can become more colorful (Çiftçi and Aydın, 2014; Malik, 2002). The concept of multiculturalism and multicultural education emerged in terms of individual and cultural differences in education process and started to take part in education (Cirık, 2008).

Nowadays, multicultural and multicultural education represents multicultural education. Multicultural education; argues that all individuals from language, religion, gender, social class, race and different cultures should have a fair and equal education opportunity (Marangoz, Aydın and Adıgüzel, 2015; Chisholm, 1994). Aydin (2013) states that people living in a harmony with different races, religions, languages are rich, that these values enrich society and produce solutions to the social problems that may arise in the future. In addition, education for cultural differences is seen as a means of producing solutions to problems related to education (Cirık, 2008). According to Banks and Ambrosio (2002), multicultural education is an effort to promote equality and fairness among students from different cultures in schools. The most important goal of multicultural education is to "restructure the schools and education system and thus to provide students with the knowledge and skills to be treated in different ethnic groups" (Aydın, 2012: 36). Multicultural education has a significant impact in educating students who are sensitive, respectful and tolerant to cultural differences in countries where cultural differences are important and effective. 
Individual characteristics and differences that are important in education process are among the factors that make multicultural education compulsory. Because the students in the educational environment with different gender, mouth, language, learning styles come with features. Students are considered to be important in terms of social welfare by accepting it naturally in the development of knowledge, tolerance and sensitivity related to different cultures (Gay, 1994; Polat, 2009; Yurdabakan, 2002). Therefore, many countries have developed training programs for multicultural education. However, because of the differences in the socio-cultural conditions of each country, there are differences in the approaches and programs of multicultural education (Keskin and Yaman, 2014; Polat and K1lıç, 2013). This reveals the necessity of evaluating each country within its own conditions and shaping the practices based on socio-cultural differences.

Teacher characteristics are more important in terms of the importance of multicultural education and effective education in societies where cultural differences are high. It is more difficult and complicated to meet the learning needs and preferences of these students in schools and classrooms where students with different language, religion, tradition and tradition are common (Brown \& Kysilka, 2002; Gay, 1994; Toprak, 2008). Although the cultural differences mentioned in each society are more or less, these differences are more evident in some countries and the social structure is built on this cultural diversity. Naturally, this diversity is reflected in schools and classes. One of the countries with the most cultural differences is Kosovo. Sira Different communities of ethnic origin, such as "Rom, Gorani, Serb, in Kosovo, along with Turks, Albanians, Bosnians", live together (Koro, 2008: 17).

The multicultural social structure of the Republic of Kosovo requires cultural and individual differences in education (Koro and Topsakal, 2007). In this context, in order to develop a multicultural and different ethnic democracy society in Kosovo, new structure and program work has been started in the Kosovo education system after 1999. In 2002, the new program was put into practice and the system was changed to Bologna in higher education (Safçı \& Koro, 2008). In order to reflect the characteristics of the communities living in Kosovo into educational programs, special commissions are being created from different communities for language, history, music and fine arts. Apart from Serbs, a unified education system has been developed by giving importance to the language, history, art and traditions of all other ethnic communities living in Kosovo (Safci and Koro, 2008).

Multicultural education in societies where cultural diversity is high is important in terms of meeting the learning needs of students and developing the culture of living together. The existence of multicultural education program schemes does not mean that this education is implemented effectively. The program design is as important as multicultural education takes in practice. Therefore, it is important for multicultural education to determine the classroom practices of the teachers who are the implementers of the programs and the demographic variables (gender, professional seniority, mother tongue, level, branches) affecting these practices.

\section{Method}

In this study, relational scanning model was used. Screening models are research approaches that aim to describe a situation that exists in the past or the present. The subject, subject, or object, which is the subject of the research, is tried to be defined as it is and within its own conditions. There is no attempt to change them in any way asar (Karasar, 2008: 77).

To determine whether Turkish, Albanian and Bosnian teachers working in high schools and elementary schools differ in terms of various demographics (gender, mother tongue, ethnicity, religious affiliation, professional seniority, stage and branch) a causal comparison study was conducted. In the causal comparison model, it aims to determine the causes and consequences of the differences between groups of people without any intervention on the conditions and participants (Büyüköztürk et al., 2011: 15). In this research model, cause and effect relationships can be determined. It can be determined in the natural environment (Gay and Airasian, 2003) which are the independent variables or variables that are effective on a dependent variable (Gay and Airasian, 2003).

\subsection{Working Groups}

The study population consists of 4760 teachers in schools in Kosovo (Prizren, Pristina) and its districts (Recane, Restelisa, Mamusa) who teach in Turkish, Albanian and Bosnian languages. In the sample selection, easy-to-reach sampling method was preferred for schools in provincial and district centers. Because, in this method, the researcher chooses a situation that is close and easy to access (Şimşek \& Yeardırım, 2006). 1005 teachers from the study population were included in the study, the obtained forms, 30 of them were not included in the study and a total of 975 people were included in the sample. A sufficient size sampling is required to ensure that the sample is adequately representative of the universe (Balc1, 2005). 556 (57.03\%) of the teachers in the sample were female and 419 (42.97\%) were male. There are no Turkish and Albanian teachers in the districts of Reçane and Restelitsa. In Pristina, the number of Turkish teachers was taken because of the low number of students. 


\subsection{Data Collection Tool}

In order to determine the in-class activities of teachers for multicultural education, the literature on the subject was searched. In this context, the questionnaires and scales used in the programs, teacher guides and similar researches, which were developed for the purpose of developing multicultural education in the world, were examined. In the light of the data obtained, item pool of 5-point Likert-type teachers for multicultural education scale consisting of 29 items, which includes the basic activities of teachers about the cultural differences within the class and the way in which these activities are included, has been formed. The pool of substances was converted into scale after passing the expert opinion. Is used Likert Scale, $5=$ Strongly Agree, 4 = Agree, 3 = Undecided, $2=$ Disagree and $1=$ Strongly Disagree.

\subsection{Data Analysis}

A total of 975 teachers participated in the çe Classroom Practices İçi scale for multicultural education prepared for this research. In the analysis of the data, analysis was done by using descriptive and one way analysis of variance to determine whether the classroom practices of teachers about teaching cultural differences are differentiated by various variables. The Kruskal Wallis $\mathrm{H}$ test was used to determine the differences in the cases where the variances were not homogeneous and the Mann Whitney $\mathrm{U}$ test was used for the difference. Descriptive analysis and mean and standard deviation were examined. The values of Table 1 were used to interpret the means. For all analyzes, significance was taken .005 . The analyzes were performed using SPSS program.

Table 1. Average Interval Rating Value

\begin{tabular}{ccc}
\hline Range & Value & Review \\
\hline $1.00-1.79$ & I strongly disagree & Negative \\
$1.80-2.59$ & Disagree & Negative \\
$2.60-3.39$ & Undecided & Negative \\
$3.40-4.19$ & Agree & Positive \\
$4.20-5.00$ & Strongly Agree & Positive \\
\hline
\end{tabular}

\subsection{Findings}

In order to determine whether teachers' practices related to multicultural education differ in terms of gender, professional seniority, mother tongue, level and branch, they were analyzed by Independent Groups t-Test, Levene Station, Kruskal Wallis H test. Analysis results are presented in the tables below.

Table 2. Independent Groups t Test Analysis Results of the Classroom Practices of Multicultural Education

\begin{tabular}{|c|c|c|c|c|c|c|c|c|c|}
\hline & \multirow[b]{2}{*}{ Gender } & \multirow[b]{2}{*}{$\mathbf{N}$} & \multirow[b]{2}{*}{$\overline{\mathbf{x}}$} & \multicolumn{3}{|c|}{ Levene Test } & \multirow[b]{2}{*}{$\mathbf{t}$} & \multirow[b]{2}{*}{ sd } & \multirow[b]{2}{*}{$\mathbf{p}$} \\
\hline & & & & SS & $\mathbf{F}$ & $\mathbf{P}$ & & & \\
\hline \multirow{2}{*}{ Method-Technical Use } & Female & 556 & 4.11 & .63 & \multirow{2}{*}{.085} & \multirow{2}{*}{$.770^{*}$} & \multirow{2}{*}{-.205} & \multirow{2}{*}{973} & \multirow{2}{*}{$.837 *$} \\
\hline & Male & 419 & 4.12 & .63 & & & & & \\
\hline \multirow{2}{*}{ Event Design } & Female & 556 & 4.09 & .63 & \multirow{2}{*}{.090 } & \multirow{2}{*}{$.764 *$} & \multirow{2}{*}{-.663} & \multirow{2}{*}{973} & \multirow{2}{*}{$.507 *$} \\
\hline & Male & 419 & 4.12 & .65 & & & & & \\
\hline \multirow{2}{*}{ Considering Individual Differences } & Female & 556 & 3.78 & .77 & \multirow{2}{*}{-3.303} & \multirow{2}{*}{$.022 *$} & \multirow{2}{*}{-2.013} & \multirow{2}{*}{931.213} & \multirow{2}{*}{$.044 *$} \\
\hline & Male & 419 & 3.88 & .72 & & & & & \\
\hline \multirow{2}{*}{ Overall Average } & Female & 556 & 3.99 & .56 & \multirow{2}{*}{.001} & \multirow{2}{*}{$.971 *$} & \multirow{2}{*}{-1.204} & \multirow{2}{*}{973} & \multirow{2}{*}{$.229^{*}$} \\
\hline & Male & 419 & 4.03 & .58 & & & & & \\
\hline
\end{tabular}

$* \mathrm{p}>.013$

When Table 2 is examined, a significant difference $(t=-1.204 ; \mathrm{p}$ $<.05)$ was not determined between female $(\overline{\mathrm{x}}=3.99)$ and Male $(\overline{\mathrm{x}}=$ 4.03) in general practices of teachers regarding multicultural education. The results of the study showed that gender difference is not an important factor other than "Considering Individual Differences". 
Table 3. The Descriptive Analysis of Teachers' Classroom Practices for Multicultural Education in Terms of Professional Severity Variables and the Results of Homogeneity Test of Variances

\begin{tabular}{|c|c|c|c|c|c|c|}
\hline \multirow{2}{*}{ Scale } & \multirow{2}{*}{ Mesleki Kıdem } & \multirow{2}{*}{$\mathbf{N}$} & \multirow{2}{*}{$\overline{\mathrm{x}}$} & \multirow{2}{*}{ SS } & \multicolumn{2}{|c|}{ Levene İstatistiği } \\
\hline & & & & & $\mathbf{F}$ & $\mathbf{P}^{*}$ \\
\hline \multirow{6}{*}{ Method-Technical Use } & 1- $1-5$ year & 178 & 4.16 & .54 & \multirow{6}{*}{2.360} & \multirow{6}{*}{$.052 *$} \\
\hline & 2- 6-10 year & 208 & 4.08 & .72 & & \\
\hline & 3-11-15 year & 144 & 4.08 & .56 & & \\
\hline & 4- 16-20 year & 115 & 4.11 & .59 & & \\
\hline & 5- 20 years and up & 330 & 4.10 & .64 & & \\
\hline & Total & 975 & 4.11 & .62 & & \\
\hline \multirow{6}{*}{ Event Design } & $1-1-5$ year & 178 & 4.10 & .56 & \multirow{6}{*}{1.824} & \multirow{6}{*}{$.122 *$} \\
\hline & 2- 6-10 year & 208 & 4.13 & .71 & & \\
\hline & 3- 11-15 year & 144 & 4.01 & .60 & & \\
\hline & 4- 16-20 year & 115 & 4.04 & .60 & & \\
\hline & 5- 20 years and up & 330 & 4.13 & .64 & & \\
\hline & Total & 975 & 4.10 & .63 & & \\
\hline \multirow{6}{*}{ Considering Individual Differences } & $1-1-5$ year & 178 & 3.97 & .65 & \multirow{6}{*}{2.386} & \multirow{6}{*}{$.051^{*}$} \\
\hline & 2- 6-10 year & 208 & 3.86 & .78 & & \\
\hline & 3- $11-15$ year & 144 & 3.77 & .67 & & \\
\hline & 4- $16-20$ year & 115 & 3.82 & .80 & & \\
\hline & 5- 20 years and up & 330 & 3.75 & .78 & & \\
\hline & Total & 975 & 3.82 & .75 & & \\
\hline \multirow{6}{*}{ Overall Average } & 1-1-5 year & 178 & 4.08 & .49 & \multirow{6}{*}{1.738} & \multirow{6}{*}{$.139 *$} \\
\hline & 2- 6-10 year & 208 & 4.03 & .64 & & \\
\hline & 3-11-15 year & 144 & 3.95 & .50 & & \\
\hline & 4- $16-20$ year & 115 & 3.99 & .52 & & \\
\hline & 5- 20 years and up & 330 & 3.99 & .59 & & \\
\hline & Total & 975 & 4.01 & .56 & & \\
\hline
\end{tabular}

According to the results of the descriptive analysis in Table 3, the highest mean score $(\overline{\mathrm{x}}=4.08)$ belongs to teachers with $1-5$ years of seniority, while the lowest average $(\overline{\mathrm{x}}=3.95)$ belongs to teachers who have a seniority of 11-15 years. In the analysis of Levene statistic, it was determined that the variances were homogeneous both in the scale and in the sub-dimensions. One
Way Analysis of Variance was performed to determine whether the difference was significant. Tukey analysis was performed to determine the differences between the groups. The results of the research are presented in Table 4.

Table 4. The results of one-way analysis of variance in terms of professional seniority variable of teachers in multicultural education

\begin{tabular}{llcccccc}
\hline Scale & & Squeare Totalı & Sd & Squeare Mean & $\mathbf{F}$ & $\mathbf{p}$ & Tukey \\
& Between Groups & .741 & 4 & .185 & .468 & $.759^{*}$ Fark Yok \\
Method-Technical Use & In-group & 383.890 & 970 & .396 & & \\
& Total & 384.631 & 974 & & & \\
\hline \multirow{2}{*}{ Event Design } & Between Groups & 2.083 & 4 & .521 & $1.282 .275^{*}$ Fark Yok \\
& In-group & 394.147 & 970 & .406 & & \\
& Total & 396.230 & 974 & & & \\
& Between Groups & 6.259 & 4 & 1.565 & $2.792 .025^{*}$ Fark Yok \\
Considering Individual Differences & In-group & 543.610 & 970 & .560 & & \\
& Total & 549.869 & 974 & & & \\
\hline \multirow{5}{*}{ Overall Average } & Between Groups & 1.418 & 4 & .355 & $1.103 .354^{*}$ Fark Yok \\
& In-group & 311.751 & 970 & .321 & & \\
& Total & 313.169 & 974 & & & \\
\hline
\end{tabular}


According to the results of the study, there was no significant difference between the scores obtained from the overall scale
$\left(\mathrm{F}_{4 ; 970}=1.103 ; \mathrm{p}>.013\right)$ and the sub-dimensions of multicultural education in terms of teachers' professional seniority variable.

Table 5. The Descriptive Analysis of Teachers' Classroom Applications for Multicultural Education in Terms of Mother Language Variable and the Homogeneity of Variances Test Results

\begin{tabular}{|c|c|c|c|c|c|c|}
\hline \multirow{2}{*}{ Scale } & \multirow[b]{2}{*}{ Mother Touge } & \multirow[b]{2}{*}{$\mathbf{N}$} & \multirow[b]{2}{*}{$\overline{\mathrm{x}}$} & \multicolumn{3}{|c|}{ Levene Statistic } \\
\hline & & & & SD & $\mathbf{F}$ & $\mathbf{p}^{*}$ \\
\hline \multirow{4}{*}{ Method-Technical Use } & 1-Turkish & 196 & 4.14 & .57 & \multirow{4}{*}{1.028} & \multirow{4}{*}{$.104 *$} \\
\hline & 2-Albanian & 606 & 4.11 & .65 & & \\
\hline & 3-Bosnian & 173 & 4.07 & .59 & & \\
\hline & Total & 975 & 4.11 & .63 & & \\
\hline \multirow{4}{*}{ Event Design } & 1-Turkish & 196 & 4.00 & .64 & \multirow{4}{*}{.430} & \multirow{4}{*}{$.268^{*}$} \\
\hline & 2-Albanian & 606 & 4.15 & .62 & & \\
\hline & 3-Bosnian & 173 & 4.03 & .67 & & \\
\hline & Total & 975 & 4.10 & .63 & & \\
\hline \multirow{4}{*}{ Considering Individual Differences } & 1-Turkish & 196 & 3.95 & .67 & \multirow{4}{*}{.962} & \multirow{4}{*}{$.305^{*}$} \\
\hline & 2-Albanian & 606 & 3.75 & .80 & & \\
\hline & 3-Bosnian & 173 & 3.94 & .62 & & \\
\hline & Total & 975 & 3.82 & .75 & & \\
\hline \multirow{4}{*}{ Overall Average } & 1-Turkish & 196 & 4.03 & .56 & \multirow{4}{*}{.794} & \multirow{4}{*}{$.452^{*}$} \\
\hline & 2-Albanian & 606 & 4.00 & .57 & & \\
\hline & 3-Bosnian & 173 & 4.01 & .54 & & \\
\hline & Total & 975 & 4.01 & .56 & & \\
\hline
\end{tabular}

According to the results of the descriptive analysis in Table 5, the highest mean score $(\overline{\mathrm{x}}=4.03)$ was for teachers with Turkish mother tongue and the lowest average $(\overline{\mathrm{x}}=4.00)$ was for teachers with Albanian mother tongue. Tukey analysis was conducted to determine the differences in which groups. The results of the analysis are presented in Table 6.

Table 6. The Results of One-Way Variance Analysis of the Classroom Applications of Multicultural Education of Teachers in Terms of Mother Language Variable

\begin{tabular}{|c|c|c|c|c|c|c|c|}
\hline Scale & & Total Square & sd & Squares Mean & $\mathbf{F}$ & $\mathbf{p}$ & Tukey \\
\hline \multirow{3}{*}{ Method-Technical Use } & Between Groups & .470 & 2 & .235 & .594 & $.552^{*}$ & Fark Yok \\
\hline & In-group & 384.161 & 972 & .395 & & & \\
\hline & Total & 384.631 & 974 & & & & \\
\hline \multirow{3}{*}{ Event Design } & Between Groups & 4.432 & 2 & 2.216 & 5.497 & $.004 * *$ & $1<2$ \\
\hline & In-group & 391.798 & 972 & .403 & & & \\
\hline & Total & 396.230 & 974 & & & & \\
\hline \multirow{3}{*}{$\begin{array}{l}\text { Considering Individual } \\
\text { Differences }\end{array}$} & Between Groups & 8.930 & 2 & 4.465 & 8.023 & $.000 * *$ & $1,3>2$ \\
\hline & In-group & 540.939 & 972 & .557 & & & \\
\hline & Total & 549.869 & 974 & & & & \\
\hline \multirow{3}{*}{ Overall Average } & Between Groups & .103 & 2 & .051 & .159 & $.853^{*}$ & Fark Yok \\
\hline & In-group & 313.067 & 972 & .322 & & & \\
\hline & Total & 313.169 & 974 & & & & \\
\hline
\end{tabular}

$* \mathrm{p}>.05 ; * * \mathrm{p}<.013$

According to the results of the analysis, there was no significant difference in terms of the mother tongue variable in MethodTechnical Use dimension $\left(\mathrm{F}_{2 ; 972}=.594 ; \mathrm{p}>.05\right)$. When Bonferroni correction was performed $(\mathrm{p}=.05 / 4=.013)$ no significant difference was observed ( $p>.05)$. In the "Event Design" dimension, a significant difference was found in terms of the mother tongue variable $\left(\left(\mathrm{F}_{2 ; 972}=5.497 ; \mathrm{p}<.05\right)\right.$. When Bonferroni correction was performed $(\mathrm{p}=.05 / 4=.013)$, there was a significant difference $(p<.013)$. In the Tukey analysis to determine the source of the difference, it was found that the average of teachers in Albanian native language $(\bar{x}=4.15)$ was higher than the average of Turkish teachers $(\overline{\mathrm{x}}=4.00)$. 
Significant differences were found in terms of the mother tongue variable in "Considering Individual Differences" $\left(\mathrm{F}_{2 ; 972}=8.023\right.$; $\mathrm{p}<.05)$. When Bonferroni correction was performed $(\mathrm{p}=.05 / 4=.0125)$, a significant difference was observed $(\mathrm{p}<.013)$. In the Tukey analysis to determine the source of the difference, the average of the Turkish native speaker $(\overline{\mathrm{x}}=3.95)$ and the teachers in Bosnian as the mother tongue $(\overline{\mathrm{x}}=3.94)$; It was determined that the teachers with Albanian native language were higher than their average $(\overline{\mathrm{x}}=3.75)$. There was no significant difference in terms of Overall Averages of teachers' practices on multicultural education $\left(\mathrm{F}_{2 ; 972}=.159 ; \mathrm{p}>.05\right)$. When Bonferroni correction was performed $(\mathrm{p}=.05 / 4=.013)$ there was no significant difference $(\mathrm{p}>.013)$.

Table 7. Descriptive Analysis and Variance Homogeneity Test Results of Classroom Teachers in Multicultural Education Classroom

\begin{tabular}{|c|c|c|c|c|c|c|}
\hline \multirow{2}{*}{ Scale } & \multirow{2}{*}{ School Grades } & \multirow{2}{*}{$\mathbf{N}$} & \multirow{2}{*}{$\overline{\mathrm{x}}$} & \multirow{2}{*}{ SS } & \multicolumn{2}{|c|}{ Levene Statistic } \\
\hline & & & & & $\mathbf{F}$ & $\mathbf{p}$ \\
\hline \multirow{4}{*}{ Method-Technical Use } & 1- Basic training & 337 & 4.22 & .57 & \multirow{4}{*}{2.688} & \multirow{4}{*}{$.069 *$} \\
\hline & 2- Lower Secondary Education (6-9 class) & 320 & 4.17 & .58 & & \\
\hline & 3- Upper Secondary School (high school) & 318 & 3.93 & .68 & & \\
\hline & Total & 975 & 4.11 & .62 & & \\
\hline \multirow{3}{*}{ Event Design } & 1- Basic training & 337 & 4.23 & .58 & \multirow{3}{*}{4.660} & \multirow{3}{*}{$.010^{* *}$} \\
\hline & 2- Lower Secondary Education (6-9 class) & 320 & 4.13 & .58 & & \\
\hline & 3- Upper Secondary School (high school) & 318 & 3.92 & .70 & & \\
\hline \multirow{5}{*}{ Considering Individual Differences } & Total & 975 & 4.10 & .63 & \multirow{5}{*}{2.283} & \multirow{5}{*}{$.102 *$} \\
\hline & 1- Basic training & 337 & 3.90 & .73 & & \\
\hline & 2- Lower Secondary Education (6-9 class) & 320 & 3.88 & .71 & & \\
\hline & 3- Upper Secondary School (high school) & 318 & 3.68 & .78 & & \\
\hline & Total & 975 & 3.82 & .75 & & \\
\hline \multirow{4}{*}{ Overall Average } & 1- Basic training & 337 & 4.12 & .50 & \multirow{4}{*}{3.777} & \multirow{4}{*}{$.023 * *$} \\
\hline & 2- Lower Secondary Education (6-9 class) & 320 & 4.06 & .52 & & \\
\hline & 3- Upper Secondary School (high school) & 318 & 3.84 & .63 & & \\
\hline & Total & 975 & 4.01 & .56 & & \\
\hline
\end{tabular}

$* \mathrm{p}<.05 ; * * \mathrm{p}>.05$

According to the results of the study in Table 7, the highest average $(\overline{\mathrm{x}}=4.12)$ is the teachers working in Basic training while the lowest average $(\bar{x}=3.84)$ is the teachers working in the upper secondary education. In all sub-dimensions and across the scale, the average of teachers in all teaching levels is high. In the analysis of Levene statistic, it was determined that the variances in the scale Differ Method-Technical Use and Considering Individual Differences was homogeneous. In the mean of others, variances are heterogeneous.

Table 8. One-way analysis of variance in terms of the variable in the classroom of teachers in multicultural education

\begin{tabular}{llcccccc}
\hline Scale & \multicolumn{1}{c}{ Squeare Total } & sd & Squeare Mean & F & p & Tukey \\
\hline \multirow{2}{*}{ Method-Technical Use } & Between Groups & 15.433 & 2 & 7.717 & 20.316 & $.000 *$ & $1,2>3$ \\
& In-group & 369.198 & 972 & .380 & & & \\
& Total & 384.631 & 974 & & & & \\
\hline \multirow{2}{*}{ Considering Individual Differences } & Between Groups & 9.661 & 2 & 4.830 & 8.691 & $.000 *$ & $1,2>3$ \\
& Total & 540.208 & 972 & .556 & & & \\
& & 549.869 & 974 & & & & \\
& & & & & &
\end{tabular}

According to the results of the analysis, değiş Method-Technical Use 2 dimension was found to have a significant difference in terms of the classroom variable where teachers work $\left(\mathrm{F}_{2: 972}=\right.$ 20.316; $\mathrm{p}<.05)$. When Bonferroni correction was performed $(\mathrm{p}=$ $.05 / 2=.025)$, a significant difference was observed $(\mathrm{p}<.025)$. In the Tukey analysis conducted to determine the source of the difference, it was determined that the average of the teachers working in Basic education $(\overline{\mathrm{x}}=4.22)$ and the average of the teachers working in Lower Secondary Education $(\overline{\mathrm{x}}=4.17)$ were higher than the average of the teachers working in Upper Secondary Education $(\overline{\mathrm{x}}=3.93)$. 
In the anlamlı Considering Individual Differences 91 dimension, a significant difference was found in terms of the school grade variable $\left(\mathrm{F}_{2 ; 972}=8.691 ; \mathrm{p}<.05\right)$. When Bonferroni correction was performed $(\mathrm{p}=.05 / 2=.025)$ it was observed that the difference was significant $(\mathrm{p}<.025)$. In the Tukey analysis conducted to determine the source of the difference, the average of the teachers working in Basic training $(\overline{\mathrm{x}}=3.90)$ and the average of the teachers working in Lower Secondary Education $(\bar{x}=3.88)$ were found to be higher than the average of the teachers working in Upper Secondary Education $(\overline{\mathrm{x}}=3.68)$.
Kruskal Wallis $\mathrm{H}$ test was applied to determine whether there is any difference between us Event Design is in which the variances are not homogeneous and the practices of the teachers towards multicultural education in the classroom. The Mann Whitney U Test was used for the analysis. The results of the analysis are presented in Table 9.

\section{Table 9. Kruskal Wallis H Test Analysis Results in terms of the Tier Variable of the Teachers in Multicultural Education Classroom}

Practices

\begin{tabular}{|c|c|c|c|c|c|c|}
\hline & Section & $\mathbf{N}$ & Order Average & $X^{2}$ & sd $\quad$ p & Source of Difference \\
\hline \multirow{4}{*}{ Event Design } & 1- Basic training & 337 & 544.47 & 34.707 & $2.000 *$ & $1,2>3$ \\
\hline & 2- Lower Secondary Education (6-9 class) & 320 & 499.09 & & & \\
\hline & 3- Upper Secondary School (high school) & 318 & 417.00 & & & \\
\hline & Total & 975 & & & & \\
\hline \multirow{4}{*}{ Overall Average } & 1- Basic training & 337 & 538.10 & 34.365 & $2.000 *$ & $1,2>3$ \\
\hline & 2- Lower Secondary Education (6-9 class) & 320 & 508.77 & & & \\
\hline & 3- Upper Secondary School (high school) & 318 & 414.01 & & & \\
\hline & Total & 975 & & & & \\
\hline
\end{tabular}

According to the Kruskal Wallis H test results, = Event Design iştir dimension was found to be significantly different in terms of the teacher's variable $\left(X^{2}=34.707 ; \mathrm{p}<.05 / 2\right)$. In order to determine the source of the difference, in the Mann Whitney $U$ analysis, the average of the teachers working in the Basic training (Rank = 544.47) and the Lower Secondary Education (Sequence = 499.09) was higher than the rank average of the teachers working in the upper secondary level (Order $=417.00$ It was determined to be larger.
A significant difference was found in terms of the classroom variable of the teachers $\left(X^{2}=34.365 ; \mathrm{p}<.05 / 2\right)$. In the Mann Whitney $\mathrm{U}$ analysis to determine the source of the difference, it was found that the average of the teachers who worked in the Basic Education $($ Rank $=538.10)$ and Lower Secondary Education $($ Order Average $=538.77)$ was higher than the rank average of the teachers working in the Upper Secondary Level (Order $=414.01$ It was determined to be larger. 
Table 10. Descriptive Analysis of Classroom Applications of Multicultural Education of Teachers in terms of Branch Variables and Results of Homogeneity Test of Variances

\begin{tabular}{|c|c|c|c|c|c|}
\hline \multirow{2}{*}{ Scale } & \multirow{2}{*}{ Branşlar } & \multirow{2}{*}{$\mathbf{N}$} & \multirow{2}{*}{$\overline{\mathrm{x}}$} & \multicolumn{2}{|c|}{ Levene İstatistiği } \\
\hline & & & & $\mathbf{F}$ & $\mathbf{P} *$ \\
\hline \multirow{9}{*}{ Method-Technical Use } & 1-Pre-school teaching & 41 & 4.28 .54 & \multirow{9}{*}{.988} & \multirow{9}{*}{$.439 * *$} \\
\hline & 2-Classroom teaching & 289 & 4.21 .58 & & \\
\hline & 3-Turkish teacher & 87 & 4.25 .64 & & \\
\hline & 4-Math teaching & 89 & 3.94 .64 & & \\
\hline & 5-English teacher & 101 & 4.14 .52 & & \\
\hline & 6-Natural Science teacher & 139 & 3.96 .69 & & \\
\hline & 7-Social science Teacher & 99 & 4.04 .71 & & \\
\hline & 8-Others & 130 & 4.03 .60 & & \\
\hline & Total & 975 & 4.11 .63 & & \\
\hline \multirow{9}{*}{ Event Design } & 1-Pre-school teaching & 41 & 4.29 .60 & \multirow{9}{*}{.595} & \multirow{9}{*}{$.760 * *$} \\
\hline & 2-Classroom teaching & 289 & 4.22 .58 & & \\
\hline & 3-Turkish teacher & 87 & 4.21 .62 & & \\
\hline & 4-Math teaching & 89 & 3.96 .66 & & \\
\hline & 5-English teacher & 101 & 3.99 .67 & & \\
\hline & 6-Natural Science teacher & 139 & 3.98 .64 & & \\
\hline & 7-Social science Teacher & 99 & 4.08 .63 & & \\
\hline & 8-Others & 130 & 4.00 .67 & & \\
\hline & Total & 975 & 4.10 .63 & & \\
\hline \multirow{9}{*}{ Considering Individual Differences } & 1-Pre-school teaching & 41 & 4.13 .59 & \multirow{9}{*}{.818} & \multirow{9}{*}{$.572 * *$} \\
\hline & 2-Classroom teaching & 289 & 3.87 .75 & & \\
\hline & 3-Turkish teacher & 87 & 3.89 .79 & & \\
\hline & 4-Math teaching & 89 & 3.67 .78 & & \\
\hline & 5-English teacher & 101 & 3.73 .78 & & \\
\hline & 6-Natural Science teacher & 139 & 3.78 .72 & & \\
\hline & 7-Social science Teacher & 99 & 3.82 .71 & & \\
\hline & 8-Others & 130 & 3.80 .75 & & \\
\hline & Total & 975 & 3.82 .75 & & \\
\hline \multirow{9}{*}{ Overall Average } & 1-Pre-school teaching & 41 & 4.23 .48 & \multirow{9}{*}{.853} & \multirow{9}{*}{$.543 * *$} \\
\hline & 2-Classroom teaching & 289 & 4.10 .51 & & \\
\hline & 3-Turkish teacher & 87 & 4.12 .61 & & \\
\hline & 4-Math teaching & 89 & 3.86 .61 & & \\
\hline & 5-English teacher & 101 & 3.95 .55 & & \\
\hline & 6-Natural Science teacher & 139 & 3.91 .57 & & \\
\hline & 7-Social science Teacher & 99 & 3.98 .60 & & \\
\hline & 8-Others & 130 & 3.95 .57 & & \\
\hline & Total & 975 & 4.01 .56 & & \\
\hline
\end{tabular}

$* \mathrm{p}>.05$

According to the results of the descriptive analysis in Table 10, the highest mean score $(\bar{x}=4.23)$ was used for pre-school teachers while the lowest mean $(\overline{\mathrm{x}}=3.86)$ was for the mathematics teachers. 
Table 11. The Results of One-Way Variance Analysis of the Classroom Applications of Multicultural Education of Teachers in terms of Branch Variables

\begin{tabular}{|c|c|c|c|c|c|c|c|}
\hline Scale & & Squeare Total & sd & Squeare Mean & $\mathbf{F}$ & $\mathbf{p}$ & Tukey \\
\hline & Between Groups & 12.494 & 7 & 1.785 & 4.638 & $.000^{*}$ & $2,3>4,6$ \\
\hline \multirow{2}{*}{ Method-Technical Use } & In-group & 372.136 & 967 & .385 & & & \\
\hline & Total & 384.631 & 974 & & & & \\
\hline \multirow{3}{*}{ Event Design } & Between Groups & 12.431 & 7 & 1.776 & 4.474 & $.000^{*}$ & $2>4,5,6,8$ \\
\hline & In-group & 383.799 & 967 & .397 & & & \\
\hline & Total & 396.230 & 974 & & & & \\
\hline \multirow{3}{*}{ Considering Individual Differences } & Between Groups & 8.178 & 7 & 1.168 & 2.086 & $.043 * *$ & Fark Yok \\
\hline & In-group & 541.691 & 967 & .560 & & & \\
\hline & Total & 549.869 & 974 & & & & \\
\hline \multirow{3}{*}{ Overall Average } & Between Groups & 9.705 & 7 & 1.386 & 4.418 & $.000^{*}$ & $1,2>4,6$ \\
\hline & In-group & 303.464 & 967 & .314 & & & \\
\hline & Total & 313.169 & 974 & & & & \\
\hline
\end{tabular}

$* \mathrm{p}<.013 ; * * \mathrm{p}>.013$

According to the results of Table 11, Method-Technical Use 7 $\left(\mathrm{F}_{7: 967}=4.638 ; \mathrm{p}<.05\right)$, Significant differences were determined in terms of "Event Design" $\left(\mathrm{F}_{7: 967}=4.474 ; \mathrm{p}<.05\right)$ and teachers' overall mean scores of teaching practices on cultural differences $\left(\mathrm{F}_{7 ; 967}=4.418 ; \mathrm{p}<.05\right)$. In the Tukey analysis to determine the source of the difference, it was determined that the average of the teachers in the Method-Technical Use dimension $(\overline{\mathrm{x}}=4.21)$ was higher than the average of Turkish teachers $(\bar{x}=4.25)$, Mathematics $(\bar{x}=3.94)$ and Science teachers $(\bar{x}=3.96)$. In the

\section{Discussion, Conclusion and Recommendations}

A total of 975 Turkish, Albanian and Bosnian teachers from Prizren, Pristina, Reçana, Restelitsa and Mamuşa provinces participated in this study. In-Class Practices Scale 1 for the teaching of cultural differences was developed and applied to teachers in the context of this research. In order to determine the validity and reliability of the scale, firstly, expert opinion was given and linguistic equivalence was provided because it was prepared in Albanian, Bosnian and Turkish. 490 teachers were pre-tested (pilot). The Cronbach Alpha coefficient was calculated to determine the reliability of the data. The Cronbach Alpha reliability analysis coefficient of the scale is .87 .

According to the results of the research, it was determined that teachers' practices for multicultural education were high in both general and sub-dimension averages. There is also homogeneity among teachers' opinions. In his study, Banks (2013) stated that multicultural education is an approach that advocates that all individuals, regardless of gender, social status, language, religion, race and culture, benefit from equal educational opportunities in the school environment. In this context, in the multicultural education process, it is inevitable that teachers should create an effective learning environment that includes cultural differences for students who have different language, religion, ethnic groups
"Event Design" dimension, it was determined that the average of the teachers $(\bar{x}=4.22)$, the mathematics teachers $(=3.96)$, the English teachers $(\bar{x}=3.99)$, the Science teachers $(\bar{x}=3.98)$ and the in "Others" teachers were higher than the average teachers $(\overline{\mathrm{x}}$ $=4.00)$. In terms of Overall Average, it was determined that the average of Preschool $(\overline{\mathrm{x}}=4.23)$ and Class teachers $(\overline{\mathrm{x}}=4.10)$ was higher than the average of Mathematics $(\overline{\mathrm{x}}=3.86)$ and Science teachers $(\bar{x}=3.91)$.

and culture in the classroom (Başbay et al., 2013). It is important for teachers to have high class practices for multicultural education and to have low diversity among teachers' practices, to be respectful and tolerant to different cultures and to ensure equality of opportunity. In her study, Vassallo (2012) found that gender was not an effective variable in teaching ability. Bulut and Başbay (2015) reached the same conclusion. The results of the study partially support the researches in the literature.

In the classroom practices of multicultural education, there is no difference in terms of the teachers' seniority in terms of scale and the meaning of the scale. There is no difference in the practices of teachers regarding multicultural education according to the seniority of teachers, and teachers having low and high seniority in the same environment can be explained with the information and experience sharing about the teaching-learning process to be applied for the multicultural education, the activities to be designed and the method-technique to be used. Fox and Gay (1995), teachers often do not share different cultures, experiences and CVs in multicultural classes, argued that the process of education and teaching may be a major obstacle. Akkoyunlu (1995), in his study, stated that nowadays teacher roles have changed, and teachers return to the state that is not the teacher but to the students and their colleagues how they reach the information. 
In the multicultural education practices of teachers, Activity Design and Individual Differences Consideration "dimensions were significantly different in terms of native language variable. The fact that the teachers with Turkish native language are lower in the Activity Design than in the teachers with Albanian mother tongue shows that they need more education in this subject. According to Kaya and Aydın (2014), in order for teachers to be effective multicultural educators, they must first continue to develop, research and change themselves. Ladson-Billings (2000), in the context of multicultural education in order to be effective in the classroom to be a teacher in the individual differences of students, learning styles, taking into account the culture and at the same time, students can be trusted by providing confidence in them.

In this context, researchers emphasized the importance of providing the knowledge and skills necessary to work with multicultural content and student communities with ethnic, cultural, social and racial diversity (Banks, 2013; Gay, 2002). On the other hand, it was determined that teachers with Turkish and Albanian native speakers took more attention to the teaching practices for dikkate Taking Individual Differences into consideration than the teachers with Bosnian mother tongue. The fact that teachers with Bosnian native speakers are more likely to work in rural areas and have less experience because they meet students from a smaller number of different cultures may have an impact on this difference. Heidari et al. (2012), in their studies, stated that they have an impact on the activities to be applied in the classroom environment by working in the existing institutions in cultural richness societies.

It is seen that the variables of school level are a factor that influences teachers' classroom practices related to multicultural education. According to the results of the analysis, it was determined that the teachers working in Basic Education (1-5 grade) and the teachers working in lower secondary education (69 classes) were more in-class practices towards multicultural education and the teachers working in Upper Secondary Education (high school) were higher than in-class practices. The differences in the practices of teachers towards multicultural education can be explained by the fact that teachers who work in basic education, and partly in lower secondary education, spend more time with their students, considering individual and learning differences, but also by observing cultural differences more. The religious, linguistic, sexual class and cultures of the teachers working at the primary level have the potential to affect the activities of multicultural education, method-technical knowledge, vocational seniority and classroom practices (Brown, 2007; Polat, 2009). In studies (Banks, 2007; Gay, 1994; Neuharth-Pritchett et al., 2001) will apply the program, the appropriate methods and techniques for multicultural education, selecting and diversifying tools and tools to create a learning environment and has measure learning Teachers.

According to the results of the study, it can be said that the branch variable is a factor affecting the classroom practices of multicultural education. According to the results of the analysis, the applications of Preschool and Class teachers towards multicultural education are higher than those of Mathematics and Science teachers. This difference can be explained by the effect of the fact that preschool and classroom teachers are graduates of education faculties. If teachers want to teach cultural differences and effectively, students with linguistic, religious, ethnic and cultural diversity need to understand how they learn (Gay, 2014). Studies conducted in this context (Middleton, 2001; Valentiin, 2006) showed that there are positive changes in multicultural education, positive and self-efficacy, and in-class activities of multicultural education in professional life.

According to the results of this study, it is possible to prevent the pre-service teachers from teaching the cultural differences during the undergraduate period and to be partially affected by the disadvantages of the pre-service teachers in the multicultural education process due to lack of professional experience and lack of knowledge. The provision of in-service trainings for the teaching of cultural differences for Turkish, Albanian and Bosnian-speaking teachers can lead to an increase in the quality of in-class practices of teachers for multicultural education. This study was conducted in accordance with the data obtained from Turkish, Albanian and Bosnian teachers working in the provinces and districts of Prizren, Prishtinë / Priština, Reçane and Restelitsa. At the same time, teachers from all over Kosovo who have different ethnic backgrounds (Serbian teachers working in the Mitrovica region) will be able to provide a comprehensive perspective on multicultural education in Kosovo. In-class activity levels of teachers about the teaching of cultural differences can be examined through observations and research can be done to reveal the different dimensions of multicultural education through qualitative data.

\section{References}

1. Akkoyunlu, B. (1995). Bilgi teknolojilerinin okullarda kullanımı ve öğretmenlerin Rolü. Hacettepe Üniversitesi Eğitim Fakültesi Dergisi, 11(11), 105109.

2. Aydın, H. (2013). Dünyada ve Türkiye'de Çokkültürlü Eğitim Tartışmaları ve Uygulamaları. Ankara: Nobel Yayıncilık. 
3. Aydın, H. (2012). Multicultural Education Curriculum Development in Turkey. Mediterranean Journal of Social Science, 3(3), 277-287

4. Balcı, A. (2005). Sosyal Bilimlerde Araştırma. Ankara: PegemA Yayıncılık.

5. Banks, J. A. (2013). Çokkültürlü Eğitime Giriş. (Çev. Aydın, H.). Ankara: Anı Yayınları.

6. Banks, J. A. (2007). Diversity and citizenship education: Global perspectives. Jossey-Bass, An Imprint of Wiley. 10475 Crosspoint Blvd, Indianapolis, IN 46256.

7. Banks J. A. ve Ambrosio, J. (2002). Encyclopedia of Education: Multicultural Education. New York: Macmillan.

8. Başbay, A. Kağnıcı, Y. D. ve Sarsar, F. (2013). Eğitim Fakültelerinde Görev Yapmakta Olan Öğretim Elemanlarının Çokkültürlü Yeterlik Algılarının İncelenmesi. International Periodical For The Languages, Literature and History of Turkish or Turkic Volume, 8(3), 47-60.

9. Brown, M. N. (2007). Educating all students: Creating culturally responsive teachers, classrooms, and schools. Intervention in School and Clinique, 43(1), 57-62.

10. Brown, S. C. ve Kysilka, M. (2002). Applying Multicultural and Global Concepts in the Classroom and Beyond. Boston, MA: Allyn ve Bacon.

11. Bulut, C. ve Başbay, A. (2015). Öğretmenlerin çokkültürlü yeterlik algılarının incelenmesi. Kastamonu Eğitim Dergisi, 23(3), 957978.

12. Büyüköztürk, Ş., Çokluk, Ö. ve Köklü, N. (2011). Sosyal Bilimler için İstatistik. (11. Baskı). Ankara: Pegem Akademi Yayıncılık.

13. Cırık, İ. (2008). Çokkültürlü eğitim ve yansımaları. Hacettepe Üniversitesi Ĕ̆itim Fakültesi Dergisi, 34, 27-40.

14. Chisholm, I. M. (1994). Preparing teachers for multicultural classrooms. The Journal of Educational Issues of Language Minority Students, 14, 43-68.

15. Çiftçi, Y. ve Aydın, H. (2014). Türkiye'de çokkültürlü eğitimin gerekliliği üzerine bir çalışma. SDÜ Fen Edebiyat Fakültesi, Sosyal Bilimler Dergisi, 33, $197-$ 218.

16. Fox, W. ve Gay, G. (1995). Integrating multicultural and curriculum principles in teacher education. Peabody Journal of Education, 70(3), 64 - 82.

17. Gay, G. (2014). Culturally Responsive Teaching Theory, Research and Practice. (Çeviri: Aydın, H.). Ankara: Anı Yayıncilık.
18. Gay, G. (2002). Preparing for Culturally Responsive Teaching. Journal of Teacher Education, 53, 106-116.

19. Gay, G. (1994). A Synthesis of Scholarship in Multicultural Education. Urban Monograph Series. Office of Educational Research and Improvement. North Central Regional Educational Lab., Oak Brook, IL. ERIC, ED 378287.

20. Gay, L. R. ve Airasian, P. (2003). Education research. Competencies for Analysis and Applications, New Jersey.

21. Heidari, F., Nourmohammadi, E. ve Nowrouzi, H. (2012). On the Relationship between Iranian EFL Teachers' Self-efficacy Beliefs and Their Teaching Styles. International Journal of Linguistics, 4(3), 536550.

22. Karasar, N. (2008). Bilimsel Araştırma Yöntemi: Kavramlar, Illkeler, Teknikler. 18. Basım. Ankara: Nobel Yayın Dağıtım.

23. Kaya, İ. ve Aydın, H. (2014). Çoğulculuk, Çokkültürlü ve Çokdilli Eğitim. Ankara: Anı yayıncilık.

24. Keskin, Y. ve Yaman, E. (2014). İlköğretim Sosyal Bilgiler programı ve ders kitaplarında yeni bir paradigma: Çokkültürlü eğitim. Turkish Studies International Periodical For The Languages, Literature and History of Turkish or Turkic, 9(2), 933960.

25. Koro, B. (2008). Tarih 9. Priștine: Libri Shkollor Yayınevi.

26. Koro, B. ve Topsakal, C. (2007). Kosova'da Yaşayan Türkçe Eğitim. Prizren: Bay Yayınları.

27. Ladson-Billings, G. (2000). Fighting for our lives preparing teachers to teach African American students. Journal of teacher education, 51(3), 206214.

28. Malik, H. (2002). Lebanon as an Experiment in Multicultural Interdependence. Lebanon's Second Republic: prospects for the twenty-first century.

29. Marangoz, G., Aydın, H. ve Adıgüzel, T. (2015). Öğretmenlerin çokkültürlü eğitime karşı algısı. International Periodical For The Languages, Literature and History of Turkish or Turkic, 10(7), 709-720

30. Middleton, V. A. (2001). Increasing preservice teachers' diversity beliefs and commitment. The Urban Review, 33(4), 343-361.

31. Neuharth-Pritchett, S., Reiff, J. C. ve Pearson, C. A. (2001). Through the eyes of preservice teachers: Implications for the multicultural . Journal of Research in Childhood Education, 15(2), 256-269. 
32. Polat, S. (2009). Öğretmen adaylarının çokkültürlü eğitime yönelik kişilik özellikleri. International Online Journal of Educational Sciences 1(1), 154164.

33. Polat, İ. ve Kılıç, E. (2013). Türkiye'de çokkültürlü eğitim ve çokkültürlü eğitimde öğretmen yeterlilikleri. Yüzüncü Year Üniversitesi Eğitim Fakültesi Dergisi, 10(1), 352-271.

34. Safçı, N. ve Koro, B. (2008). Kosova'da Türkçe Eğitimde Öğretmen Kadrosu. Prizren: Kosova Türk Öğretmenler Derneği Yayınları.

35. Şimşek, H. ve Yeardırım, A. (2006). Nitel Araștırma Yöntemleri. Ankara: Seçkin Yayıncılık.

36. Toprak, G. (2008). Öğretmenlerin Çokkültürlü Tutum Ölçeği'nin (Teacher Multicultural Attitude Survey) Güvenirlik ve Geçerlik Çalışması. Yayınlanmamış Yüksek Lisans Tezi, Gaziosmanpasa Üniversitesi Sosyal Bilimler Enstitüsü, Tokat.

37. Valentiin, S. (2006). Addressing diversity in teacher education programs. Education, 127(2), 196-202.

38. Vassallo, B. (2012). Am I culturally competent? A study on multicultural teaching competencies among school teachers in Malta. The Journal Multiculturalism in Education, 8.

39. Yurdabakan, İ. (2002). Küreselleşme Konusundaki Yaklaşımlar ve Eğitim. Eğitim Araştırmaları, 6, 6164. 